Article

\title{
Transport Infrastructure Development, Public Performance and Long-Run Economic Growth: A Case Study for the Eu-28 Countries
}

\author{
Elena Cigu ${ }^{1} * \mathbb{E}$, Daniela Tatiana Agheorghiesei ${ }^{1}$, Anca Florentina Gavriluţă (Vatamanu) ${ }^{1}$ \\ and Elena Toader ${ }^{2}$ \\ 1 Faculty of Economics and Business Administration, Alexandru Ioan Cuza of Iasi, 11 Carol I Boulevard, \\ 700506 Iasi, Romania; d_corodeanu@yahoo.com (D.T.A.); gavriluta.anca@yahoo.com (A.F.G.V.) \\ 2 Faculty of Medicine, Grigore T. Popa University of Medicine and Pharmacy of Iasi, 700511 Iasi, Romania; \\ toader.elena@yahoo.com \\ * Correspondence: elena.chelaru@uaic.ro; Tel.: +40-745-666-028
}

Received: 21 November 2018; Accepted: 22 December 2018; Published: 22 December 2018

\begin{abstract}
This paper examines the link between the transport infrastructure and the economic performance in the EU-28 countries, over the period of time 2000-2014, using panel data methods. Firstly, we aim to provide the theoretical background of the transport infrastructure development, public sector performance and economic growth. The paper's key point is the detailed look at the components of transport infrastructure, analyzing the implications of the policy-makers based on a production function and in order to test the policy implication, factor analysis is also employed. The results show significant effects from transport infrastructure components even after institutional and other factors are controlled for. From the path analysis results, the study confirm the alternative hypothesis, outlining the unidirectional long-run causality relationship between growth, transport infrastructure and Public Sector Performance. Transport infrastructure status (measured thought index of transport) has significant impact on economic development with coefficient estimate. The public performance indicators influence the way to economic growth. On the one hand, the corruption, the regulatory environment, size shadow economy, infant mortality, income inequality, inflation and unemployment rate negatively affect the economic growth, and on the other hand there is a strong positive relationship between the quality of the judiciary, education achievement, life expectancy and economic growth.
\end{abstract}

Keywords: transport infrastructure; economic growth; sustainable development; public performance

\section{Introduction}

The transport infrastructure in all 28 countries of the European Union (EU-28) has undergone the fastest development in the last decades, and the impact of the transportation on sustainable development and economic growth has become a concern for policy-makers as well for economists or entrepreneurs. To identify multiple impacts of transportation infrastructure development, the studies mainly focus both on statistical results [1], and economic fundamentals theories. Even if the effect of transport infrastructure development in relationship with economic growth has been receiving more attention and debate and has been empirically investigated, there are still many aspects that should be taken into account for more detailed expertise. However, most papers analyze the implication of transport infrastructure on sustainable economic growth [2-19], losing sight of it the quality of public decision-making and the reliance of public policies on economic reasoning. Completing the existing studies, this paper explores the interdependence between economic growth, transport infrastructure 
and policy implication, specifically from the point of public sector performance status in the EU-28 over the period of time 2000-2014. The paper contributes to the literature on the transport-led economic growth hypothesis because there are few studies examining the relationship between the transport infrastructure and the economic growth at the level of the EU-28 over the recent years taking into account the period of global crisis, the diversities of the economies in the structure and the most important, this study it is the first one that analyses from the perspective of public sector performance status. By the fact that it is necessary to create commonality and to apply growth equation by taking care of spuriously implication in the model results. Another novelty aspect of this research is the development of a transport index. In this context, the paper contributes to creating a comprehensive view on the relationship between the transport infrastructure developments, public performance and economic growth, considering that can bring added value in the field of the literature. The results can be usefully in supporting not only the future decisions in terms of public-private partnership or investments in transport infrastructure, but also reflect the need for consolidating a viable strategy that makes the poor public policy outcomes more responsive.

The goal of this paper is twofold, theoretical and empirical. Firstly, at the theoretical level, we intend to highlight the state of knowledge on the relationship between the transport infrastructure, the public sector performance and the economic growth. Secondly, assimilating the results of previous studies, we intend to develop an econometric model for evaluating the interference of the status of transport infrastructure and public performance indicators with the economic growth in the EU-28 over the period of time 2000-2014. Considering that all the variables regarding the status of transport show systematic and fundamental interdependencies, in order to create commonality and apply a growth equation, we will use factor analysis methodology. Moreover, we intend to create an index of transport status, which takes into consideration all the variables regarding transport infrastructure status.

The paper is divided into three main parts. Section 2 summarizes representative existing studies providing the theoretical background of the multiple impacts of the transportation infrastructure for an in-depth understanding. Section 3 describes the method, variables and data sources. Section 4 summarizes the results of the empirical study conducted on the EU-28, over the period 2000-2014. Finally, according to the results, this paper ends with conclusions and references.

\section{Literature Review}

The contribution of transport infrastructure to economic growth and the causal relationship between them has received great attention from the empirical studies in the economic literature. Transport infrastructure has been always for decision-makers a political instrument reflected in government programs and subsequently implemented through public policies to reduce disparities and inequalities, as well as to promote economic growth [20]. Economically, infrastructure is expensive, requiring substantial capital that takes a considerable share in public expenditure and pressure on public authorities, but as a part of public capital, especially transport infrastructure is the most powerful instrument in stimulating the economies of the world, being considered in a metaphoric way the "wheels" of any economic activity [21]. Moreover, transport infrastructure is classified as a productive public expenditure [22-24] because the economy can benefit from transport facilities by accelerating access to the services and opening up of the exporting market, by increasing the market and labors mobility, reducing the wealth gaps and improving social welfare saving time and reducing business costs [18]. Munnell [25] concluded that a greater output filled with more private investment and more employment growth is generated usually by those states that developed policies and have invested more in infrastructure. The economy of scale can only be achieved when the development of transportation makes the spatial expansion of the market possible [26-28]. Canning and Pedroni [29] and Crafts [30] explain that there are associated costs for governments investing in transport infrastructure. In their paper, Canning and Pedroni [29] show that infrastructure does tend to cause long-run economic growth and suggest that infrastructure investment asks for major public capital that implies the reduction of investment in other types of capital, and in this context 
must exist a growth-maximizing infrastructure level. In their opinion, Canning and Pedroni [29] as the economic theory stipulates, there is an optimal level of infrastructure maximizing the growth rate and above this optimal level the effect is the reducing of the overall growth. Crafts [30] highlights in his research paper that the development of transport infrastructure requires large expenditure from of central and local budgets, and these costs are inevitably reflected and managed through fiscal policy instruments, such as taxes and fees. Theoretically, based on how the economy is managed, the net gain from transport investment theoretically could be positive, zero or negative [14]. Investigating from the perspective of the growth impact of public infrastructure taking into account public expenditure for investment in infrastructure in stimulating the economic performance, Farhadi [18] find a positive relationship. Zhou et al. [31] comparing two countries (e.g. China and Germany) on the planning modes for major transportation infrastructure projects mainly by public budget identify as values prioritizing efficiency and effective in terms of ex post cost savings the strategies including extensive public participation for social harmony with the development of ecological consciousness.

Transport infrastructure is considered essential for increasing economic progress, could contribute to economic growth both directly and indirectly $[2-6,21,32,33]$. From the perspective of economies with developing transport infrastructure, [34], indirect effects may support industries that supply goods and services to enable the direct investment. The theory in Reference [2] points out three ways why infrastructure choices matter for economic growth: (i) Improve the overall productivity of production units [33,35]; (ii) promote technological spillovers across economies; and (iii) raise the profitability of transport-connected businesses, both by increasing their sales and by reducing their costs with production and/or delivery.

A number of studies have attempted to identify the optimal level of the transport infrastructure that can maximize in the respective stage of development of the society the growth rate. Majority of the scientific papers confirm that the transport infrastructure is one of the most important contributors to economic growth, finding significant positive effects on economic growth led by transport infrastructure investment [7-10,12-14,36-38]. Aschauer [36] using as transport infrastructure variable the road density (the percent of highway mileage of deficient quality) based on panel data of 48 US states over the period of time 1960-1985 and OLS, WLS, TSLS, WTSLS methods find that the quality and quantity of highway have significant positive impact on economic growth and output elasticity is 0.22-0.30. Moomaw and Williams [7] for the same period over 48 US states using as transport infrastructure variable the density of interstate highway network and OLS method find that highway capital has a positive impact on manufacturing growth and output elasticity is 0.25 . Pereira [38] using as transport infrastructure variable highways and streets and based on time series data (1956-1997) of the US in VAR model, find that highway investment has a positive impact on the private output, with the output elasticity estimated by 0.0055 . Cantos et al. [9] using as variable the aggregate infrastructure of 17 Spanish regions over the period of time 1965-1995 and fixed-effects regressions find different results obtained by different types of transport infrastructure and by different economic sectors, but all of them mostly positive. Berechman et al. [10] using as transport infrastructure variable the highway capital stock for 48 states, 18 counties, 389 municipalities for the period of time 1990-2000 find that the investment in transport infrastructure can generate a contagion effect to space and time. Jiwattanakulpaisarn et al. [13] using as transport infrastructure variable the density of highway for 48 US states over the period of time 1984-2005 and the GMM model found that the long-run output elasticity for all roads is $0.035-0.039$, for interstate highways is 0.037 , for the non-interstate major roads is 0.038 , and for the local roads is 0.036 . From the perspective of Banister [39], reasonable quality and density of the transport network has positive effects at the subnational level for local economic growth. Deng et al. [14] consider that the contribution of transport infrastructure provision to economic activity may depend on the level of existing infrastructure accumulation, finding a non-monotonic relationship between the stock of highway provision and the long-run growth rate. Gherghina et al. [40] find that all categories of the transport infrastructure, excepting railway transport, influence positively the economic growth. 
Another important aspect of the literature is that transport infrastructure must be viewed both as a whole and by the types of transport. From the perspective of the relationship of a specific sector of transportation with the long-run economic growth, most of the studies present a positive relationship, even if the empirical methods are diverse. The positive influence of the highway and the roads on the economic growth was found using Granger-causality analysis [4], GMM model [13], or panel data regression models $[12,40,41]$. The positive relationship between the airway transport infrastructure (based on passengers or/and freight services) and the economic growth was found using fixed-effects regressions [40], Granger-causality analysis [42], autoregressive distributed lag [43], co-integration analysis and Granger-causality analysis [44]. There are also studies [12] based on alternative methods as pooled ordinary least squares, random-effects and fixed-effects panel data regression models that reflect the weak relationship with the economic growth of the airway transport infrastructure. Regarding the positive influence of the water transport infrastructure (inland waterways and maritime transport) and the size of maritime ports on the economic growth, there are studies using the fixed-effects regressions [40], Spatial-Durbin Model which controls for spatial fixed effects [45], augmented Solow model [46], alternative methods as pooled ordinary least squares, random-effects and fixed-effects panel data regression models [12], a structural equation model (SEM) [47]. Regarding the impact of railway transport, there are studies that found a positive one using Granger-causality analysis [4] or a spatial Lag Model with fixed effects [41]; and a negative one using fixed-effects regressions model [40].

Other studies [48,49] find little evidence on the relationship between transport infrastructure and economic growth. The scientific findings are so different from paper to paper, that some of them [2] developed theories on direct or indirect effects on the economic growth through the transportation intensity that has gained a great expansion over the last decades. Usually the direct effect can be the determined through and as a result of the productivity channels and the indirect effects appear as a result of the expansion of urbanization and the rise of $\mathrm{CO}_{2}$ emissions [16,50-52], which rethinks the development from a sustainable perspective.

Moreover, some theoretical and empirical studies highlight the causal relationship (unidirectional causality or bidirectional causality) between transportation activity and economic growth, where the theoretical and logical fundament is that on the one hand the improvements in transportation and greater transportation activity cause economic growth, and on the other hand the economic growth may also increase transportation activity. The results are mixed, as follows: (i) Studies that found a bidirectional Granger-causality relationship between transportation intensity and economic growth [3,40,51,53-57]; (ii) studies that found a unidirectional Granger-causality relationship between transportation intensity and economic growth [4,58-62]; (iii) studies that found a reverse unidirectional Granger-causality relationship between transportation intensity and economic growth [63,64]; (iv) studies that found no causality [65]; and (v) studies with mixed results depending on the stage of the economy of the countries where results for the developed countries show that transportation intensity bears no causal relationship to economic growth in the short-run and the explication being the fact that transportation intensity has reached a point of near saturation, but for the developing countries higher transportation intensity led to higher economic growth specifically in passenger air transportation [2]. Gherghina et al. [40] developed a study for the EU-28, over a 26-year period (1990-2016) based on estimation techniques for panel data models and found a bidirectional causal relation in the long-run between a specific sector of transportation, respectively the railways lines, regarding their length and investment in this sector and the economic growth. Also, there was find a two-way causal link which is contoured between the gross weight of seaborne goods handled in ports and economic growth.

The extension of the transport infrastructure all over the world and the development of the transportation sector as a whole are so intricate from the perspective of the effects and implications that the full dimension of sustainable development cannot be omitted by most of the recent studies from different domains. In the context of sustainable development as a desideratum of every 
society, an important part of the studies $[2,15-17,19,40,65-83]$ is more complex, being oriented to the environmental and the social dimension from the impact of transport development in relationship with the economic growth. The transport sector accounts for about a quarter of $\mathrm{CO}_{2}$ emissions globally [84]. Reducing or eliminating carbon dioxide $\left(\mathrm{CO}_{2}\right)$ emissions and other specific air pollutants from transport supposes implementation of sustainable transport policies, environmental policies, health policies, including economic instruments, and technological innovations. For the context of the EU-28 countries an important instrument for sustainable development is Europe 2020 Strategy [85] that emphasizes smart, sustainable and inclusive growth, based on indicators and targets logically connected so that all three dimensions of sustainable development can be reached. One of the most important EU flagship initiative is "Resource Efficient Europe", which can be seen as an instrument to help to decouple economic growth from the use of resources, using as methods as follows: (i) By decarbonizing the economy, with strong positive impact on the society health; (ii) by increasing the use of renewable sources; (iii) by modernizing the transport sector; and (iv) by promoting energy efficiency.

One of the most recent studies, Sun et al. [81] taking into account 83 Chinese cities over the period of time 2000-2012 and based on regression models found that in the long run, urban traffic infrastructure investment can alleviate air pollution. Gherghina et al. [40] on their study regarding the EU-28 found in the short-run, a bidirectional link occurred between carbon dioxide emissions from railway transport and economic growth, unidirectional relations appeared from economic growth to $\mathrm{CO}_{2}$ from road and domestic aviation. In their paper regarding Tunisia over the long period of time of 31 years (1980-2011), Ben Jebli and Belloumi [75] found different results that support the literature regarding the inference of the transport infrastructure with the economic growth and the environment, as follows: (i) A bidirectional causality between carbon dioxide emissions and maritime sector transport in the short-run; (ii) a unidirectional causality from the economic growth (real GDP), combustible renewables, and waste consumption, rail transport to carbon dioxide emissions in the short-run; (iii) the economic growth (real GDP) generates a decrease of the carbon dioxide emissions in the long-run; and (iv) combustible renewables, waste consumption and maritime sector transport and rail sector transport have a positive impact on $\mathrm{CO}_{2}$ in the long-run. The research of Saidi and Hammami [77] was developed using the Generalized Method of Moments (GMM) and has covered a significant number of countries, more precisely 75 countries over the recent period of time 2000-2014, finding that environmental degradation is inevitable for developing countries when is registered economic growth and as a result of the development of freight sector transport. Saboori et al. [17] have conducted an analysis over a 48-year period (1960-2008) including only the OECD countries and found a bidirectional connection between carbon dioxide emissions and economic growth in the long-run, that is positive and significant. The paper of Sobrino et al [67] on Spain over the period 1990-2010 found that the economic growth is closely related to the increase in greenhouse gas emissions. Neves et al. [76] analyzed the interactions between transport sector energy consumption, by source, growth and carbon dioxide emissions for a panel for 15 OECD countries over the period of time 1995-2014, and found that the transports fossil fuels consumption enhance the economic growth. Damania et al. [80] highlight that transport infrastructure brings economic benefits that are essential for the development. Sousa et al. [19] found that economic growth and carbon dioxide emissions from transport have an increasing monotonic relationship in Portugal. An important aspect of recent research from the perspective of sustainable development is materialized in the connection of the road pavement technologies development with the environmental protection and the economic growth [86], considering that new technologies with high performance, so called "smart technologies", generate durable road structure, reduce pollution and are based on recyclable and locally available materials. In Radziszewski et al. [86] opinion, transport infrastructure based on new technologies of the road pavement implies the government policy and the level of science.

Regarding public sector implications, even if the literature does not trigger a long overdue dialogue among transport infrastructure status, growth and public performance achieved of political leaders, the public sector performance indicators are also validated in the literature. There are some 
researchers $[23,24,32,87-89]$ that analyze the subject in different ways but with the same quintessence related to public performance status. Esfahani and Ramirez [87] highlight the institutional implications that mediate the interaction between infrastructure and economic growth. Pereira and Andraz [88] analyze public investment in transportation infrastructure and economic performance, and concluded that investing in public infrastructures by entities is justified, both from a long-term development perspective and a long-term public budgetary perspective. Agénor and Moreno-Dodson [89] analyze links between health, education, infrastructure, and growth in an endogenous growth model with transitional dynamics and highlight few policy implications.

Increasing the efficiency and the effectiveness of the public sector not only have a major influence over maintaining sustainable growth path, but can achieve superior results regarding the status of transport infrastructure.

\section{Materials and Methods}

\subsection{Sample and Variables}

The importance of the public sector in promoting the sustainable economy is recognized by the European Union that has driven the lead in efforts to act by taking care of future generations. It should be acknowledged that even if the global economic growth it has been studied in many papers by linked to infrastructure conditions, it is also important to count that all these dimensions are guided not only by international strategies to act toward environmental policies but also by political implications. In a world guided by political strategies, it is not easy to challenge the existing paradigms, since Sustainable Development Goals suppose supplementary attention to the idea of Public Policy implications. As far as Public policies are often made without much reliance on economic reasoning, policy changes, institutional arrangements and the incentives guided by political stakes can negatively impact the status of transport infrastructure development and the way to sustainable growth. In addition, behind some inappropriate policy decisions, it sometimes addresses veiled strategies that negatively impact both the community and sustainable development. For example, to put disadvantaged people to pay the price of "ecological reform" in case of France, reflects not only the implications of a veiled strategy but also the government's inability to maintain financial balance. It is well known that fuel taxes are, in France, only a form of reducing public deficits through additional taxation in order to enter the deficit area below 3\% of GDP. So, even if in the literature numerous versions of pooled OLS model have been developed to evaluate the impact of infrastructure development on economic growth, in the present paper the model proposed involves the estimation of a more conventional production function by the fact that we have included other variables that may impact growth (labor, general government expenditure, trade, energy). On the other hand, we tested the policy implication (by using public performance indicators carefully chosen and validated in the literature) and we have computed a comprehensive index that can capture the status of transport, in this way, not only eliminating the problems of interdependence, but also avoiding the multicollinearity issue in the econometric model.

By using a production function and factor analysis this research aims to assess the relationship between economic growth in the EU-28 countries over the period 2000-2014, the status of transport infrastructure and policy implications, more specifically, public performance inference. The analysis strives to highlight that it is a unidirectional long run causality between the three main dimensions above mentioned and only a strategy capable to move all the actors implied to the improvement of the EU economies can change the future conditions of development. All the data used in investigation were collected from available sources: The OECD database [90], the European Commission (Eurostat) [91], World Data Atlas [92-94], the database of World Doing Business and World Bank [95], World Economic Forum [96], The World Competitiveness Yearbook [97]. The variables used in this study and details how each indicator was built and what its measures are explained in Appendix A, Table A1.

The main purpose of this paper is to empirically test the following null hypothesis: There is no relationship between economic growth, transport infrastructure and Public Sector Performance. 
The alternative hypothesis is that there is a positive relationship between growth, transport infrastructure and Public Sector Performance.

When it comes to quantifying transport infrastructure implications on the economic growth, the studies highlighted the specific inputs and outputs, being simpler to choose the variables involved. As can be seen in Appendix A, Table A1 follow the literature $[98,99]$, we use GDP per capita based on purchasing power parity (PPP) as a dependent variable. Even if most studies use GDP at market prices (euro per capita), given the distribution of these variables and the implication on the viability of model, the chosen variable is better for provide an adequate measure of economic growth. To test the validity of a regression, the literature indicates the need to check if it is stationary or not by the Augmented Dicky Fuller (henceforth "ADF"). If it is stationary, it is indicated to work with the differences or logarithms of the series and if it is seasonal it is necessary to use moving averages or to log of the series $[4,16,98,99]$. In order to eliminate the problem of spurious regression or the existing non-linear relationship between the independent and dependent variables and to achieve a normal distribution of variables, some of the variables (except Index_Transport for example), were logarithmically transformed (see Table A2). As can be seen in Appendix A, Table A5, based on panel unit root results, economic growth and index transport series are stationary at first differences.

The first main component of transport status is Railway transport infrastructure, which has three indicators, rail lines (Rail_lines), passenger transport by type of transport (Passenger_transpbytypeoftransp) and Goods transport by rail (Goods_transpbyrail). Road transport infrastructure is composed of three sub-indicators, length of motorways and e-roads (Length_ofmotorways_e-roads), motorization rate-Cars per 1000 inhabitants (Motorisation_rate) and Goods transport by road (Goods_transpbyroad). Goods transport by inland waterways (Goods_transpbyinland_waterways) is one indicator of inland waterways transport infrastructure and sea transports of goods (Sea_transp_ofgoods) is the indicator of maritime transport infrastructure. The air transport of passengers (Air_transpofpassengers) and air transport of goods (Air_transpofgoods) are the two indicators of Air transport infrastructure. The last component of infrastructure status for specifically look into the impact of infrastructure investments on economic growth, is composed by the key determinant of performance in the transport, respectively, investments in transport infrastructure (INV_tr), which cover the sum of investments in road, rail and air transport.

Regarding public sector implications, even if the literature does not trigger a long overdue dialogue among transport infrastructure status, growth and public performance achieved of political leaders, the public sector performance indicators are also validated in the literature. There are some researchers that analyze the subject in different ways but with the same quintessence related to public performance status. Esfahani and Ramirez [87] highlight the institutional implications. Pereira and Andraz [88] analyze public investment in transportation infrastructure and economic performance. Other authors analyze the status of infrastructure from the point of public-private partnerships [100-102]. Moreover, World Bank Group highlights few policy implications and analyzes links between health, infrastructure and growth in an endogenous growth model with transitional dynamics [89].

Starting from the point that increasing the efficiency and the effectiveness of public sector not only have a major influence over maintaining sustainable growth path but can achieve superior results regarding the status of transport infrastructure, the indicators chosen for to measure the status of public performance follow Afonso, Schuknecht, and Tanzi [103,104] point of view and include opportunity indicators and standard Musgravian indicators. The components corresponding to the opportunity are: Administrative performance of the government (which include corruption, red tape, quality of judiciary and shadow economy), education (which consists of two indicators like secondary school enrolment and education achievement), health (composed by infant mortality and life expectancy). The last indicators were taken from Musgrave and reflect the goals that should be pursued by any government: Distribution (inequality of income distribution) stability and economic performance (which consists of stability of GDP growth, inflation, and unemployment rate). Having in mind the 
purpose of this paper and started from the point that all the variables regarding the status of transport shows a systematic and fundamental interdependencies, in order to create a commonality and to apply growth equation, we use factor analysis methodology and we create the index of transport status, which take in considerations all the variables regarding transport infrastructure status (see Appendix A, Table A1). To estimate the index of transport infrastructure status, we calculated the weighted average of the three factors, considering the percentage of variance for each of them (see Equation (1)), and then applying a normalization procedure validated in the literature [105] (see Equation (2)). As can be seen in Table A3, three main factors explain the evolution of the variables used. The results indicate that factor 1 , factor 2 and factor 3 have been explained $83.12 \%$ of the total variance.

$$
M=\frac{\sum_{t=1}^{n} W_{t} * V_{t}}{\sum_{t=1}^{n} W_{t}}
$$

$M=$ Aerage value

$V=$ Actual value

$W=$ Weighting factor

$N=$ Number of periods in the weighting group

$$
Z_{i j}=\frac{x_{i j-\bar{x}_{j}}}{s_{j}}
$$

$X_{i j}=$ Data for variable $j$ in sample unit $i$

$\bar{x}_{j}=$ Sample mean for variable $j$

$s_{j}=$ Sample standard deviation for variable $j$

\subsection{Empirical Model}

In order to investigate the implication of transport infrastructure status and public performance on economic growth, we follow the growth theory analysis on this subject [12,22-24] and we estimate a growth model by using Barro type framework [22], which allows us to test conditional convergence. The growth equation at time $t$ in country $i$ is give as follows (see Equation (3)):

$$
G_{i t}=a_{i t}+\alpha \ln \left(q_{i, t-1}\right)+\beta_{K_{i t}}+\gamma_{N_{i t}}+\phi_{H_{i t}}+\tau_{T_{i t}}+\beta_{1 \text { Controls }_{i t}}+\varepsilon_{i t} ; \mathrm{i}=1,2 \ldots, 28 ; \mathrm{t}=2000,2001, \ldots, 2014,
$$

where $G$ is the dependent variable and represents annual gross domestic product converted to international dollars using purchasing power parity rates, based on the 2011 International Comparison Program (ICP) round, $q$ represents stability of GDP growth; $K, N$ and $H$ denote administrative component, health and education quality respectively; $T$ is the index of infrastructure status in EU countries, $\varepsilon$ is the error term, and $a, \alpha, \beta, \gamma, \phi, \tau$ are coefficients to be estimated. By using a comprehensive index that can capture the status of transport, not only eliminate the problems of interdependence, but it also helps to avoid the multicollinearity issue in the econometric model.

In order to turn the model into a more conventional production function and to assess the independent contributions of the transport infrastructure and other variables, we used $\beta_{1 \text { Controls }}$, which represent a vector of country-level control variables catching additional features that may impact economic growth. One of the control variables used in the model consists in the labor force, the indicator comprises people ages 15 and older that supply labor for the production of goods and services during a specified period. Given that labor force size tends to vary during the year as seasonal workers enter and leave, the indicator comprises people who are currently employed and people who are unemployed but seeking work as well as first-time job-seekers, unpaid workers, family workers, or students being omitted. General government expenditure, trade and the ratio between the energy consumption of transport and GDP are other variables considered in the empirical literature to impact economic growth $[4,8,17,25,30,36,56]$. 


\section{Results and Discussion}

Given that the transport infrastructure is one of the most important elements for a country's progress and the variables regarding transport infrastructure present systematic and fundamental interdependencies, we first construct an index for measuring the status of transport infrastructure at a macro, EU level. The descriptive statistics of the variables are presented in Appendix A, Table A2. With reference to GDP per capita based on purchasing power parity (PPP) it is highlighted that it was a wide dispersion within the sample: The lowest level of GDP per capita PPP was $\$ 5,873$ for Romania in 2000, and the highest one was $\$ 101,877$ for Luxembourg in 2014. Regarding railway transport infrastructure status, it is shown that during 2000-2014, the length of railway lines recorded the highest value on the profile of Germany and concerning passenger transport by type of transport, again Germany scored the highest values (95.465 Millions of passenger-kilometers). Additionally, public performance indicators highlight significant inter-country and over time differences. Red tape, an indicator of administrative performance which highlight the regulatory environment and take into considerations days to start a business show the lowest time on the profile of some country such as Denmark (in 2011-2014 3.5 days), France (3.5 days in 2012) Netherlands (3.5 days in 2010) and on the opposite side we find Spain with 138 days in 2000. Size shadow economy, which reveals the underground economy and it is an important point in analyzing the policy implications scored the highest value on the profile of Bulgaria in 2003 (35.9) and the lowest on the profile of Austria in 2002 (7.5).

To estimate the index, we used the variables indicated in Appendix A, Table A1 for this component by applying factor analysis and we create a single index by using the retained principal components calculated through factor analysis. More specifically, we calculated the weighted average of the three factors, considering the percentage of variance for each of them, and then applying a normalization procedure. Both the results of factor analysis of the main components for estimating the status of infrastructure in the EU countries and correlation matrix indicate the strongly associated elements for considering the output of infrastructure status (see Appendix A in Table A3). Appendix A in Table A4 indicate factor loading and explained variance and show that eight variables are strongly correlated with some specific factors. The evolution of transport index is illustrated in Figure 1 an inherently indicates that in long run it is a causal relationship between transport infrastructure and economic growth. The results are in line with the theoretical and empirical literature, which provides additional arguments with respect to the infrastructure status and growth $[4,29,39,106-108]$. The novelty of the study consists in type of approach (by computing the index of infrastructure status, we have included other factors of production to turn our model into a more conventional production function and we have analyzed the policy implication), period of investigation and the manner to report the results at the EU-country level. As can be seen in Figure 1 we find the existence of unidirectional long run causality, countries that reflect high values in gross domestic product size, also record positive transport status values. Moreover, the results are validated by both economic theory and empirical research on the subject as long as economically well-known countries such as Belgium, Denmark, France, United Kingdom, Germany and Finland show positive values of the transport index and in the opposite direction, countries like Bulgaria, Hungary, Cyprus, Romania, Slovakia show negative values regarding the status of the transport infrastructure. 


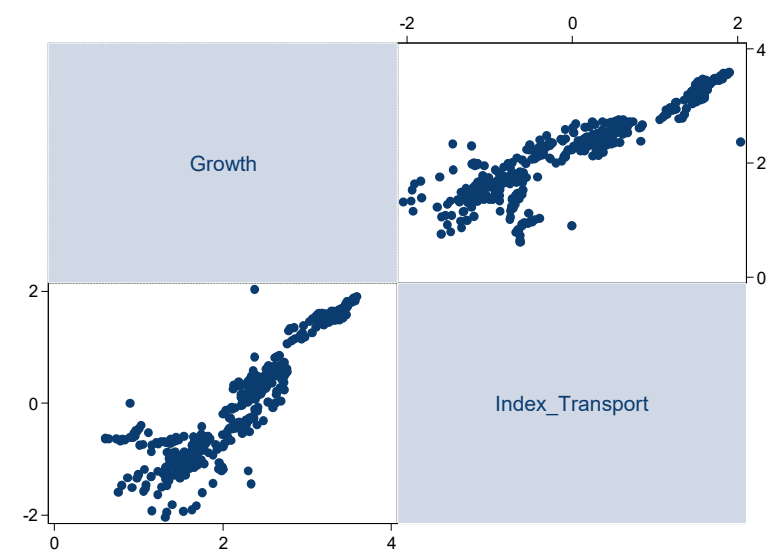

Figure 1. The evolution of transport infrastructure status and economic growth (logarithmic values in case of GDP growth) over the period 2000-2014. Source: Authors' work. Notes: For the definition of variables, please see Appendix A, Table A1.

The results presented in Table 1 reports the estimation based on pooled OLS, random-effect and fixed-effect panel data model, respectively show that some possible causality issues augment the implication of transport infrastructure and public performance on economic growth. We estimated our model specification using two different methods. Firstly, we used least-squares regression model (OLS) as a benchmark. Secondly, following previous studies [8,12], we draw on a panel fixed effects (FE). In order to test if there are country-wise differences, we have included dummies in the fixed effects model to capture the status of Southern and Eastern Europe. Since each country in the sample has its own specificity that will be kept throughout the study period, is explained the panel data methodology. More than that, the inference of different panel data techniques is explained by the desire to extract as much information as possible from the data and it is also an important way to test the robustness of the estimation results. Hausman statistic of 30.21 indicates that the fixed-effect model (model 3) is preferred.

Table 1. Main empirical results.

\begin{tabular}{cccccc}
\hline & Pooled OLS & Random Effect & Fixed Effect & $\begin{array}{c}\text { Southern } \\
\text { Europe }^{1}\end{array}$ & $\begin{array}{c}\text { Eastern } \\
\text { Europe }^{2}\end{array}$ \\
\hline GDP_percapita_ppp (-1) & 0.0021 & 0.0026 & $0.0039^{* * *}$ & $0.0029^{* *}$ & $0.0032^{* * *}$ \\
& $(3.261)$ & $(4.481)$ & $(4.513)$ & $(5.108)$ & $(4.921)$ \\
Index_Transport & -0.0278 & $-0.0526^{*}$ & $0.0526^{* * *}$ & $0.0502^{* * *}$ & 0.0262 \\
& $(-0.0212)$ & $(-0.0268)$ & $(0.0166)$ & $(0.0147)$ & $(0.0419)$ \\
CORRP & $-0.0457^{* *}$ & -0.0143 & $-0.0135^{*}$ & $-0.0103^{*}$ & $-0.0328^{* *}$ \\
& $(-0.0226)$ & $(-0.0164)$ & $(-0.0182)$ & $(-0.0239)$ & $(-0.0293)$ \\
RedType & $-0.0030^{* * *}$ & $-0.00133^{*}$ & $-0.00149^{* * *}$ & $-0.000635^{* *}$ & -0.00123 \\
& $(-0.000408)$ & $(-0.000712)$ & $(-0.000284)$ & $(-0.000215)$ & $(-0.000722)$ \\
QJud & -0.0269 & 0.0127 & $0.0157^{* *}$ & $0.0511^{* *}$ & $0.00801^{*}$ \\
& $(-0.0306)$ & $(0.0248)$ & $(0.0203)$ & $(0.0507)$ & $(0.0257)$ \\
SizeShE & $-0.0114^{* * *}$ & $-0.00705^{* * *}$ & $-0.00762^{* * *}$ & -0.0014 & $-0.00775^{* * *}$ \\
& $(-0.00128)$ & $(-0.00201)$ & $(-0.00139)$ & $(-0.00151)$ & $(-0.00226)$ \\
SecSchEnr & -0.00110 & $0.00110^{*}$ & $0.000890^{*}$ & $0.000973^{* *}$ & 0.00228 \\
& $(-0.000598)$ & $(0.000561)$ & $(0.000513)$ & $(0.00106)$ & $(0.00258)$ \\
EdAchiev & -0.00235 & -0.000276 & $0.00115^{*}$ & $0.00794^{* * *}$ & $0.00254^{*}$ \\
InfantMort & $(-0.00154)$ & $(-0.00161)$ & 0.0026 & 0.000769 & 0.00163 \\
& $-0.0707^{* * *}$ & $-0.111^{* * *}$ & $-0.107^{* * *}$ & $-0.0943^{* * *}$ & $-0.109^{* * *}$ \\
LifeExpect & $(-0.00572)$ & $(-0.0125)$ & $(-0.00501)$ & $(-0.0148)$ & $(-0.0154)$ \\
& $0.0474^{* * *}$ & $0.0497^{* * *}$ & $0.0471^{* * *}$ & $0.0424^{* * *}$ & $0.021^{*}$ \\
& $(0.00525)$ & $(0.0145)$ & $(0.0056)$ & $(0.00647)$ & $(0.0181)$ \\
\hline
\end{tabular}


Table 1. Cont.

\begin{tabular}{|c|c|c|c|c|c|}
\hline & Pooled OLS & Random Effect & Fixed Effect & $\begin{array}{l}\text { Southern } \\
\text { Europe }{ }^{1}\end{array}$ & $\begin{array}{c}\text { Eastern } \\
\text { Europe }^{2}\end{array}$ \\
\hline IncIneq & $\begin{array}{c}-0.00661^{* * *} \\
(-0.00236)\end{array}$ & $\begin{array}{l}-0.0115^{* *} \\
(-0.00458)\end{array}$ & $\begin{array}{l}-0.0105^{* * *} \\
(-0.0028)\end{array}$ & $\begin{array}{l}-0.00294 * \\
(-0.00312)\end{array}$ & $\begin{array}{l}-0.00684^{* *} \\
(-0.00562)\end{array}$ \\
\hline Infl & $\begin{array}{l}-0.00474 * * \\
(-0.00241)\end{array}$ & $\begin{array}{l}-0.00282 \\
(-0.00239)\end{array}$ & $\begin{array}{l}-0.00254 \text { * } \\
(-0.0013)\end{array}$ & $\begin{array}{l}-0.0039 * \\
(-0.00305)\end{array}$ & $\begin{array}{l}-0.000118 * \\
(-0.00291)\end{array}$ \\
\hline Unemp_rate & $\begin{array}{l}-0.0159^{* * *} \\
(-0.00201)\end{array}$ & $\begin{array}{l}-0.0169 * * * \\
(-0.00187)\end{array}$ & $\begin{array}{l}-0.0171 * * * \\
(-0.00137)\end{array}$ & $\begin{array}{l}-0.0144^{* * *} \\
(-0.00214)\end{array}$ & $\begin{array}{l}-0.0208 * * * \\
(-0.00358)\end{array}$ \\
\hline LaborF & $\begin{array}{l}-4.4610 \\
(-1.2209)\end{array}$ & $\begin{array}{l}-2.2509 \\
(-2.4208)\end{array}$ & $\begin{array}{l}-1.2306^{*} \\
(-2.4409)\end{array}$ & $\begin{array}{c}-4.0609 \text { *** } \\
(-1.1009)\end{array}$ & $\begin{array}{l}-3.3508 \\
(-4.3608)\end{array}$ \\
\hline Trade & $\begin{array}{l}0.00173^{* * *} \\
(0.000167)\end{array}$ & $\begin{array}{l}0.00170 * * * \\
(0.000467)\end{array}$ & $\begin{array}{l}0.00184^{* * *} \\
(0.000233)\end{array}$ & $\begin{array}{l}0.000433^{*} \\
(0.000247)\end{array}$ & $\begin{array}{l}0.00316^{* *} \\
(0.00105)\end{array}$ \\
\hline GenGovExp & $\begin{array}{l}-0.00168 \\
(-0.0016)\end{array}$ & $\begin{array}{l}-0.000562 * \\
(-0.00208)\end{array}$ & $\begin{array}{c}0.000637^{* *} \\
(0.00135)\end{array}$ & $\begin{array}{c}0.00178^{* *} \\
(0.0011)\end{array}$ & $\begin{array}{c}0.0105^{*} \\
(0.00418)\end{array}$ \\
\hline EnergyTransp & $\begin{array}{l}-0.000275 * \\
(-0.000894)\end{array}$ & $\begin{array}{c}-0.000707^{* *} \\
(-0.000939)\end{array}$ & $\begin{array}{l}-0.00058^{* * *} \\
(-0.000543)\end{array}$ & $\begin{array}{c}-0.000516^{* * *} \\
(-0.000605)\end{array}$ & $\begin{array}{c}-0.000728^{* * *} \\
(-0.00124)\end{array}$ \\
\hline _cons & $\begin{array}{c}6.688^{* * *} \\
(0.481)\end{array}$ & $\begin{array}{c}6.677^{* * *} \\
(1.117)\end{array}$ & $\begin{array}{c}6.847^{* * *} \\
(0.445)\end{array}$ & $\begin{array}{c}7.089^{* * *} \\
(0.516)\end{array}$ & $\begin{array}{c}8.565^{* * *} \\
(1.235)\end{array}$ \\
\hline F & $657.63^{* * *}$ & $108.71^{* * *}$ & $49.25^{* * *}$ & $36.13^{* * *}$ & $40.12^{* * *}$ \\
\hline Hausman & & & $30.21 * * *$ & & \\
\hline $\mathrm{N}$ & 417 & 417 & 417 & 113 & 120 \\
\hline$R^{2}$ & 0.527 & 0.631 & 0.659 & 0.671 & 0.6928 \\
\hline
\end{tabular}

Notes: ${ }^{1}$ Following United Nations Statistics Division in Southern Europe we included following countries: Croatia, Greece, Italy, Malta, Portugal, Slovenia, and Spain. ${ }^{2}$ Eastern Europe include Bulgaria, Hungary, Poland, Romania, Slovakia and given the fact that United Nations Statistics Division included until 2017 the Baltic countries in southern Europe, we maintained the same geographic logic in the analysis and we also have included Latvia, Lithuania, and Estonia. Source: Authors' computations. Superscripts $* * * * *, *$, denote statistical significance at the $1 \%, 5 \%$ and $10 \%$ levels, respectively $\left(* * *<0.01,{ }^{* *} p<0.05,{ }^{*} p<0.1\right)$.

Considering that the database used in this study is a panel-type base, the efficiency frontier for infrastructure development and public performance for the entire analyzed period can be estimated aggregate for the EU-28 countries and in order to analyses if there are country-wise differences we included dummies in the fixed effects model to capture the differences between Southern and Eastern Europe. It has been claimed that building an index can help assess the links between infrastructure and economic development more systematically [109]. The empirical results shown in Table 1 indicate that transport infrastructure status (measured thought the index of transport) has significant impact on economic development with coefficient estimate. The lack of improvements on the profile of Eastern Europe might have been caused by the inappropriate design of policy, which obstruct the accession of Eastern European economies. Hungary, Poland, Bulgaria, Romania still represent a small share of the EU's overall GDP and income divergence continued to consolidate uneven development [110]. In addition, it is shown that the magnitude of the problems in terms of low economic efficiency in the East European countries, are corelated also with the status of infrastructure. For instance, it is highlighted on the profile of Hungary that the annual loss of GDP is related to the poor level of telecommunication services [111,112]. In terms of efficiency, effectiveness and performance of the public sector, results indicate that public performance indicators influence the way to economic growth. Corruption, regulatory environment, size shadow economy, infant mortality, income inequality, inflation and unemployment rate negatively affect economic growth. In line with this, Palei [113] reinforces an interesting point of view, showing that given the fact that corruption is a key institutional trap that prevents the development of the national economy, can impact also the level of authority of customers contracting system, which leads then to low performance regarding transport infrastructure. In addition, even if unemployment and poor education are like a backbone fracture in an economy and Hanushek and Wößmann [114] indicate that education is a central part of most development strategies, contrary to our expectations, on the profile of Eastern Europe secondary school enrolment and unemployment rate does not impact economic growth. A possible explication in this case can be the fact that according to the Okun's Law [115], it is an inverse linkage between the unemployment rate and economic growth. More than that, literature point on the profile of Eastern Europe the applicability 
of this concept. Soylu et al. [116] highlighted for example that a 1\% rise in GDP would fall the unemployment rate by $0.08 \%$. Regarding the interaction with size shadow economy, the results show that the underground economy negatively affect growth. In line with this, according to Schneider [117] and Schneider and Williams [118] it is noticed that shadow economy is an important point in the analysis of the policy implications and highlight that the higher (lower) the unemployment quota (GDP growth), the higher the incentive to work in the shadow economy. Quality of judiciary, education achievement and life expectancy positively affect growth. With respect to the first variable, regarding the quality of the judiciary, the literature suggests a strong causal link between regulatory quality and economic performance, being clear that institutional quality has implications on transport and communications infrastructure status [119-121]. Moreover, Easterly [122] finds evidence in favor of a positive relationship between quality of life across nations and income per capita, this judgment supporting our results regarding the negative impact of income inequality on economic growth.

\section{Conclusions}

The transport infrastructure is an important element towards economic growth, ensuring mobility for people, efficiency and effectiveness in the distribution of resources. On the other hand, higher economic growth impact positive revenues and subsist in greater demand on good infrastructure, which stimulates further improvement of transport conditions [17]. Even if most studies analyzed the unidirectional long-run causality relationship between growth and transport infrastructure, as far as Public policies are often made without much reliance on economic reasoning, policy changes, institutional arrangements and the incentives guided by political stakes can negatively impact the status of transport infrastructure development and the way to sustainable growth. In addition, behind some inappropriate policy decisions, it sometimes addresses veiled strategies that negatively impact both the community and sustainable development.

Using a panel dataset containing information across countries and time, we investigate not only the implication of transport infrastructure on economic growth but also, the role of policy makers in explaining cross-country differences in EU members over the period between 2000 and 2014. Contrary to previous studies, the paper's key point is the detailed look at the components of transport infrastructure and analyzes the implications of the policy-makers. A production function is used and in order to test the policy implication (by using public performance indicators carefully chosen and validated in the literature) factor analysis is also employed. The results show significant effects from transport infrastructure components even after institutional and other factors are controlled for.

From the path analysis results, the study confirm the alternative hypothesis, outlining the unidirectional long-run causality relationship between growth, transport infrastructure and Public Sector Performance. Transport infrastructure status (measured thought index of transport) has significant impact on economic development with coefficient estimate. As expected, public performance indicators also influence the way to economic growth. Corruption, the regulatory environment, size shadow economy, infant mortality, income inequality, inflation and unemployment rate negatively affects economic growth. There is a strong positive relationship between the quality of judiciary, the education achievement, the life expectancy and the economic growth and contrary to our expectations, on the profile of Eastern Europe, secondary school enrolment and unemployment rate does not impact economic growth. A possible explanation in this case can be the fact that according to the Okun's Law, it is an inverse linkage between the unemployment rate and economic growth. More than that, literature point on the profile of Eastern Europe that the rise in GDP can fall the unemployment rate.

Our results proved to be validated in the literature and strengthen the idea that in EU countries the improvement of transport conditions plays an important role in sustain the requirement of economic growth. Policy implication not only dictates the future throughout the sustainability path but indicate also the need for a strategy capable to move all the actors implied to the improvement of EU economies. As long as public institutions and the policy-makers decisions not only have a major influence over maintaining sustainable growth path but can achieve superior results regarding the status of transport 
infrastructure, it is required that public institution be associated towards efficiency and effectiveness. Overall, the policy-makers need to promote adequate support for that aim by consolidating the opportunity and Musgravian indicators.

A limitation of the current study ensues from the fact that public-private partnerships, along with urbanized kilometers of road and investments segregate in these two components was not considered in addition with the status of public performance indicators. For future research, this study can be extended by considering public-private partnerships, along with transport infrastructure multipliers (with cross-country differences in the values of multipliers and overtime) and the status of public performance.

Author Contributions: Conceptualization, E.C., D.T.A., A.F.G.V. and E.T.; data curation, E.C., D.T.A., A.F.G.V. and E.T.; formal analysis, E.C., D.T.A., A.F.G.V. and E.T.; methodology, E.C., D.T.A., A.F.G.V. and E.T.; resources, E.C., D.T.A., A.F.G.V. and E.T.; validation, E.C., D.T.A., A.F.G.V. and E.T.; visualization E.C., D.T.A., A.F.G.V. and E.T.; writing - original draft preparation, E.C., D.T.A., A.F.G.V. and E.T.; writing-review and editing, E.C., D.T.A., A.F.G.V. and E.T. All authors read and approved the final manuscript.

Funding: This research received no external funding.

Conflicts of Interest: The authors declare no conflict of interest.

\section{Appendix A}

Table A1. Description of the variables.

\begin{tabular}{|c|c|c|c|}
\hline Main Component & Indicator & Source & Observations \\
\hline $\begin{array}{l}\text { GDP per capita based on } \\
\text { purchasing power parity } \\
\text { (PPP) }\end{array}$ & $\begin{array}{l}\text { GDP converted to international } \\
\text { dollars using purchasing power } \\
\text { parity rates. Data are based on the } \\
2011 \text { ICP round. } \\
\text { (GDP_percapita) }\end{array}$ & World Bank [95] & $\begin{array}{l}\text { Gross domestic product (GDP) per } \\
\text { capita based on purchasing power } \\
\text { parity (PPP) is the best proxy for } \\
\text { economic growth, even if most of } \\
\text { the studies use GDP at market } \\
\text { prices (euro per capita), given the } \\
\text { stationarity of these variables and } \\
\text { the implication on viability of } \\
\text { model, some papers use the first one } \\
\text { as a proxy for sustainable economic } \\
\text { growth }[123,124]\end{array}$ \\
\hline \multirow{3}{*}{$\begin{array}{l}\text { PI- Railway transport } \\
\text { infrastructure status }\end{array}$} & $\begin{array}{l}\text { Rail lines (total route-km) } \\
\text { (Rail_lines) }\end{array}$ & $\begin{array}{l}\text { European Commission } \\
(\text { ttr00003) }\end{array}$ & $\begin{array}{l}\text { The length of railway lines, whether } \\
\text { electrified or not, on the territory of } \\
\text { the reporting country. Data } \\
\text { available for 2004-2014 }\end{array}$ \\
\hline & $\begin{array}{l}\text { Passenger transport by type of } \\
\text { transport-Millions of } \\
\text { passenger-kilometres } \\
\text { (Passenger_transpbytypeoftransp) }\end{array}$ & $\begin{array}{c}\text { European Commission } \\
(\operatorname{ttr} 00015)\end{array}$ & $\begin{array}{c}\text { Rail transport of passengers which } \\
\text { relate Rail passengers transport in } \\
\text { the Member States on its } \\
\text { national territory }\end{array}$ \\
\hline & $\begin{array}{c}\text { Goods transport by rail-million } \\
\text { tone } \mathrm{km} \\
\text { (Goods_transpbyrail) }\end{array}$ & $\begin{array}{l}\text { European Commission } \\
(\text { ttr00006) }\end{array}$ & $\begin{array}{c}\text { Rail goods transport in the Member } \\
\text { States on its national territory. Data } \\
\text { available for 2004-2014 }\end{array}$ \\
\hline \multirow{3}{*}{$\begin{array}{l}\text { Road transport } \\
\text { infrastructure status }\end{array}$} & $\begin{array}{l}\text { Length of motorways and e-roads } \\
\text { km } \\
\text { (Length_ofmotorways_e-roads) }\end{array}$ & $\begin{array}{c}\text { European Commission } \\
(\operatorname{ttr00002)}\end{array}$ & Data available for 2000-2014 \\
\hline & $\begin{array}{c}\text { Motorization rate-Cars per } 1000 \\
\text { inhabitants } \\
\text { (Motorisation_rate) }\end{array}$ & $\begin{array}{l}\text { European Commission } \\
\text { (tsdpc340) }\end{array}$ & Data available for 2000-2014 \\
\hline & $\begin{array}{l}\text { Goods transport by road } \\
\text { (Goods_transpbyroad) }\end{array}$ & $\begin{array}{c}\text { European Commission } \\
(\text { ttr00005) }\end{array}$ & Data available for 2000-2014 \\
\hline $\begin{array}{l}\text { Inland waterways } \\
\text { transport infrastructure } \\
\text { status }\end{array}$ & $\begin{array}{l}\text { Goods transport by inland } \\
\text { waterways- Million tonne-kilometre } \\
\text { (TKM) } \\
\text { (Goods_transpbyinland_waterways) }\end{array}$ & $\begin{array}{c}\text { European Commission } \\
(\mathrm{ttr00007)}\end{array}$ & Data available for 2000-2014 \\
\hline $\begin{array}{l}\text { Maritime transport } \\
\text { infrastructure status }\end{array}$ & $\begin{array}{l}\text { Sea transports of goods } \\
\text { (Sea_transp_ofgoods) }\end{array}$ & $\begin{array}{l}\text { European Commission } \\
(\operatorname{ttr} 00009)\end{array}$ & $\begin{array}{l}\text { Gross weight of goods handled in } \\
\text { all ports. Data available for } \\
\text { 2000-2014 }\end{array}$ \\
\hline
\end{tabular}


Table A1. Cont.

\begin{tabular}{|c|c|c|c|}
\hline Main Component & Indicator & Source & Observations \\
\hline \multirow[t]{2}{*}{$\begin{array}{l}\text { Air transport } \\
\text { infrastructure status }\end{array}$} & $\begin{array}{l}\text { Air transport of passengers } \\
\text { (Air_transpofpassengers) }\end{array}$ & $\begin{array}{l}\text { European Commission } \\
\quad(\operatorname{ttr} 00012)\end{array}$ & $\begin{array}{l}\text { The total number of passengers } \\
\text { carried in Europe (arrivals plus } \\
\text { departures), broken down by } \\
\text { country and by year. Data available } \\
\text { for 2000-2014 }\end{array}$ \\
\hline & $\begin{array}{l}\text { Air transport of goods (Tonnes) } \\
\text { (Air_transpofgoods) }\end{array}$ & $\begin{array}{l}\text { European Commission } \\
(\text { ttr00011) }\end{array}$ & $\begin{array}{l}\text { Freight and mail on board. Data } \\
\text { available for } 2000-2014\end{array}$ \\
\hline $\begin{array}{l}\text { Investments in transport } \\
\text { infrastructure }\end{array}$ & $\begin{array}{l}\text { Road, Rail and Air transport. } \\
\text { (INV_tr) }\end{array}$ & OECD databases [90] & $\begin{array}{l}\text { A key determinant of performance } \\
\text { in the transport, which cover the } \\
\text { sum of investments in Road, Rail } \\
\text { and Air transport. Data available for } \\
\text { 2000-2014 }\end{array}$ \\
\hline \multirow{4}{*}{ Administrative } & $\begin{array}{l}\text { Corruption } \\
\text { (CORRP) }\end{array}$ & $\begin{array}{l}\text { World Bank databases } \\
\text { [95] }\end{array}$ & $\begin{array}{l}\text { Control of corruption is an } \\
\text { important element of good } \\
\text { governance and a subcomponent of } \\
\text { one of opportunity indicators } \\
\text { regarding public performance. Data } \\
\text { available for } 2000-2014 \text {. }\end{array}$ \\
\hline & $\begin{array}{l}\text { Red tape } \\
\text { (RedTape) }\end{array}$ & $\begin{array}{c}\text { World Bank and World } \\
\text { Economic Forum [95], } \\
\text { The World } \\
\text { Competitiveness } \\
\text { Yearbook 2001, } \\
\text { "Bureaucracy" (for 2001) } \\
\text { [97] }\end{array}$ & $\begin{array}{l}\text { Highlight the regulatory } \\
\text { environment and take into } \\
\text { considerations days to start a } \\
\text { business. Data available for } \\
\text { 2000-2014 }\end{array}$ \\
\hline & $\begin{array}{l}\text { Quality of judiciary } \\
\text { (QJud) }\end{array}$ & $\begin{array}{l}\text { World Bank and World } \\
\text { Economic Forum [95], } \\
\text { The World } \\
\text { Competitiveness } \\
\text { Yearbook 2001, "Justice" } \\
\text { (for 2001) [97] }\end{array}$ & $\begin{array}{l}\text { Comprise the ability of the } \\
\text { government to formulate and } \\
\text { implement sound policies and } \\
\text { regulations that permit and promote } \\
\text { private sector development. Data } \\
\text { available for 2000-2014 }\end{array}$ \\
\hline & Size Shadow economy (SizeShE) & {$[92-94,125]$} & $\begin{array}{l}\text { The indicator includes the GDP } \\
\text { percentage of underground } \\
\text { economy and is an important point } \\
\text { in analyzing the policy implications. } \\
\text { Data available in Schneider }[92,125]\end{array}$ \\
\hline \multirow[t]{2}{*}{ Education } & $\begin{array}{l}\text { Secondary school enrolment } \\
\text { (SecScgEnr) }\end{array}$ & $\begin{array}{l}\text { World Bank [95] and } \\
\text { UNESCO statistics [126] }\end{array}$ & $\begin{array}{l}\text { Secondary school enrolment is an } \\
\text { indicator that takes into account } \\
\text { basic education that began at the } \\
\text { primary level and aims at laying the } \\
\text { foundations for lifelong. Data } \\
\text { available for 2000-2014 }\end{array}$ \\
\hline & $\begin{array}{l}\text { Education achievement } \\
\text { (EdAchiev) }\end{array}$ & OECD databases [90] & $\begin{array}{l}\text { Results obtained by the EU member } \\
\text { states in three domains. The average } \\
\text { of reading, mathematics and science } \\
\text { scores. Data available for } 2000-2014\end{array}$ \\
\hline \multirow{2}{*}{ Health } & $\begin{array}{l}\text { Infant mortality } \\
\text { (InfantMort) }\end{array}$ & $\begin{array}{c}\text { World Bank } \\
\text { databases [95] }\end{array}$ & $\begin{array}{l}\text { Mortality rate, infant (per } 1000 \\
\text { live births) }\end{array}$ \\
\hline & Life expectancy (LifeExpect) & $\begin{array}{c}\text { World Bank } \\
\text { databases [95] }\end{array}$ & Life expectancy at birth, total (years) \\
\hline Distribution & $\begin{array}{l}\text { Inequality of income distribution } \\
\text { (InqIneq) }\end{array}$ & $\begin{array}{c}\text { World Bank } \\
\text { databases [95] }\end{array}$ & $\begin{array}{l}\text { Data are based on primary } \\
\text { household survey data obtained } \\
\text { from government statistical } \\
\text { agencies and World Bank country } \\
\text { departments. Data available for } \\
\text { 2000-2014 }\end{array}$ \\
\hline
\end{tabular}


Table A1. Cont.

\begin{tabular}{|c|c|c|c|}
\hline Main Component & Indicator & Source & Observations \\
\hline \multirow{3}{*}{ Stability } & Stability of GDP growth (StabGDP) & $\begin{array}{l}\text { European Commission } \\
\text { (200801_convergence) }\end{array}$ & $\begin{array}{c}\text { Stability of GDP growth } \\
\text { Data available for 2000-2014 }\end{array}$ \\
\hline & $\begin{array}{l}\text { Inflation } \\
\text { (Infl) }\end{array}$ & $\begin{array}{c}\text { https: } \\
\text { / / www.statista.com > } \\
\text { International > EU and } \\
\text { Euro-Zone }\end{array}$ & Inflation for the period 2000-2014. \\
\hline & $\begin{array}{l}\text { Unemployment rate } \\
\text { (Unemp_rate) }\end{array}$ & $\begin{array}{c}\text { European Commission, } \\
\text { Ameco }\end{array}$ & Data available for 2000-2014 \\
\hline Index Transport & *(Index_Transport) & $\begin{array}{l}\text { Authors calculations } \\
\text { using factor analysis }\end{array}$ & $\begin{array}{l}\text { Started from the point that all the } \\
\text { variables regarding the status of } \\
\text { transport show systematic and } \\
\text { fundamental interdependencies, } \\
\text { this being the rule for applying this } \\
\text { method, in order to create a } \\
\text { commonality, we use this } \\
\text { methodology and we create the } \\
\text { index of transport status. }\end{array}$ \\
\hline \multirow{4}{*}{$\begin{array}{l}\text { Country-level control } \\
\text { variables }\end{array}$} & $\begin{array}{l}\text { Trade } \\
\text { (Trade) }\end{array}$ & $\begin{array}{l}\text { World Bank national } \\
\text { accounts data, and } \\
\text { OECD National } \\
\text { Accounts data files. }\end{array}$ & $\begin{array}{l}\text { The sum of exports and imports of } \\
\text { goods and services measured as a } \\
\text { share of the gross domestic product. }\end{array}$ \\
\hline & $\begin{array}{l}\text { Labor force, total } \\
\text { (LborF) }\end{array}$ & World Bank & $\begin{array}{l}\text { The indicator comprises people ages } \\
15 \text { and older who supply labor for } \\
\text { the production of goods and } \\
\text { services during a specified period. } \\
\text { Given that labor force size tends to } \\
\text { vary during the year as seasonal } \\
\text { workers enter and leave, the } \\
\text { indicator comprises people who are } \\
\text { currently employed and people who } \\
\text { are unemployed but seeking work } \\
\text { as well as first-time job-seekers, } \\
\text { unpaid workers, family workers, or } \\
\text { students being omitted. }\end{array}$ \\
\hline & $\begin{array}{c}\text { Energy consumption of transport } \\
\text { relative to GDP } \\
\text { (EnergyTransp) }\end{array}$ & $\begin{array}{l}\text { European Commission } \\
\text { (tsdtr100) }\end{array}$ & $\begin{array}{l}\text { The ratio between the energy } \\
\text { consumption of transport and GDP } \\
\text { (chain-linked volumes, at } 2010 \\
\text { exchange rates). The energy } \\
\text { consumed by all types of transport } \\
\text { (road, rail, inland navigation and } \\
\text { aviation) is covered, including } \\
\text { commercial, individual and public } \\
\text { transport, with the exception of } \\
\text { maritime and pipeline transport. } \\
\text { Index (2010=100) }\end{array}$ \\
\hline & $\begin{array}{l}\text { General government expenditure } \\
\text { (GenGovExp) }\end{array}$ & $\begin{array}{l}\text { European Commission } \\
\quad \text { (gov_10a_main) }\end{array}$ & $\begin{array}{l}\text { The sum of central, state and local } \\
\text { governments, and social } \\
\text { security funds. }\end{array}$ \\
\hline
\end{tabular}

Source: authors' elaboration based on empirical studies, *Index transport is based on authors' calculations. 
Table A2. Summary statistics.

\begin{tabular}{|c|c|c|c|c|c|c|c|}
\hline VARIABLES & $\mathbf{N}$ & mean & Std. Dev & $\min$ & $\max$ & Skewness & Kurtosis \\
\hline GDP_percapita_ppp & 420 & 29,308 & 14,006 & 5873 & 101,877 & 1.683652 & 8.580105 \\
\hline Rail_lines & 418 & 8276 & 8570 & 275 & 36,652 & 1.673694 & 5.266633 \\
\hline Passenger_transpbytypeoftransp & 420 & 17,350 & 24,956 & 193 & 95,465 & 1.851015 & 5.373769 \\
\hline Goods_transpbyrail & 420 & 15,978 & 20,679 & 9.251 & 115,652 & 3.03999 & 6.186078 \\
\hline Length_ofmotorways_eroads & 420 & 2373 & 3614 & 0 & 15,049 & 2.100436 & 6.186078 \\
\hline Motorisation_rate & 420 & 433.5 & 110.4 & 137 & 666 & -0.32934 & 2.875496 \\
\hline Goods_transpbyroad & 420 & 63,823 & 78,072 & 538 & 343,447 & 1.725805 & 5.0583 \\
\hline Goodstransportbyinlandwaterwa $4 \mathrm{i}$ & 420 & 15,896 & 22,959 & 2 & 80,368 & 1.135585 & 2.668621 \\
\hline Sea_transp_ofgoods & 420 & 156,102 & 199,152 & 18.19 & 963,671 & 1.539376 & 4.761394 \\
\hline Air_transpofpassengers & 420 & $3.59 \times 10^{7}$ & $5.29 \times 10^{7}$ & 361,945 & $2.20 \times 10^{8}$ & 1.880655 & 5.392483 \\
\hline Air_transpofgoods & 419 & 456,244 & 843,138 & 0 & $4.60 \times 10^{6}$ & 2.600696 & 10.09331 \\
\hline INV_tr & 420 & $1.11 \times 10^{9}$ & $1.90 \times 10^{9}$ & 0 & $1.02 \times 10^{10}$ & 2.433383 & 8.607388 \\
\hline Index_Transport & 420 & $-6.67 \times 10^{9}$ & 1 & -2.044 & 2.034 & 0.283777 & 2.02185 \\
\hline CORRP & 420 & 0.977 & 0.814 & -0.491 & 2.47 & 0.283777 & 2.02185 \\
\hline RedTape & 420 & 19.46 & 17.56 & 3.5 & 138 & 0.208339 & 1.776315 \\
\hline QJud & 420 & 1.124 & 0.514 & -0.109 & 2.098 & 2.558559 & 13.56051 \\
\hline SizeShE & 420 & 20.7 & 7.137 & 7.5 & 35.9 & -0.52062 & 2.705787 \\
\hline SecSchEnr & 417 & 105.3 & 15.3 & 79.27 & 162.3 & 1.75998 & 6.308718 \\
\hline EdAchiev & 420 & 13.99 & 6.159 & 4.7 & 29.6 & 0.82216 & 2.944262 \\
\hline InfantMort & 420 & 4.951 & 2.573 & 2 & 18.4 & 2.301892 & 9.81074 \\
\hline IncIneq & 420 & 31.05 & 3.563 & 23.7 & 39 & 0.005535 & 2.036049 \\
\hline Infl & 420 & 3.056 & 3.631 & -4.48 & 45.67 & 6.18482 & 62.20738 \\
\hline StabGDP & 420 & 539.6 & 855.6 & 4.059 & 3885 & 2.086007 & 6.406234 \\
\hline Unemp_rate & 420 & 9.001 & 4.325 & 1.9 & 27.5 & 1.419245 & 5.315914 \\
\hline LaborF & 420 & 8.515918 & $1.08 \times 10^{7}$ & 156,205 & $4.25 \times 10^{7}$ & 1.652576 & 4.6151 \\
\hline Trade & 420 & 112.553 & 61.25091 & 45.60912 & 382.2915 & 1.862028 & 6.894654 \\
\hline GenGovExp & 420 & 44.54952 & 6.419925 & 32.1 & 65.3 & 0.0757605 & 2.50088 \\
\hline EnergyTransp & 420 & 100.4048 & 8.417471 & 76.9 & 127.8 & -.0270304 & 3.237758 \\
\hline \multicolumn{8}{|c|}{ Logarithmic values } \\
\hline logGDP_percapita_ppp & & 10.17791 & 0.477373 & 8.678121 & 11.42543 & -0.41589 & 3.61756 \\
\hline logRedTape & 420 & 2.652 & 0.787 & 1.253 & 4.927 & 0.224079 & 2.329463 \\
\hline $\log$ CORRP & 420 & 0.977 & 0.814 & -0.491 & 2.47 & 0.208339 & 1.776315 \\
\hline $\log \mathrm{QJud}$ & 389 & 0.117 & 0.439 & -3.252 & 0.741 & -2.003765 & 12.49162 \\
\hline logSizeShE & 420 & 2.961 & 0.389 & 2.015 & 3.581 & -0.606817 & 2.337754 \\
\hline $\operatorname{logSecSchEnr}$ & 417 & 4.647 & 0.132 & 4.373 & 5.089 & 1.336638 & 4.896549 \\
\hline $\log$ EdAchiev & 420 & 2.544 & 0.439 & 1.548 & 3.388 & 4.896549 & 2.571019 \\
\hline logInfantMort & 420 & 1.502 & 0.418 & 0.693 & 2.912 & 0.821359 & 3.653467 \\
\hline logIncIneq & 420 & 3.429 & 0.116 & 3.165 & 3.664 & -0.174284 & 2.072932 \\
\hline $\log I n f l$ & 397 & 0.858 & 0.912 & -7.393 & 3.821 & -2.338702 & 20.62374 \\
\hline $\operatorname{logStabGDP}$ & 420 & 5.085 & 1.678 & 1.401 & 8.265 & 0.012711 & 2.192459 \\
\hline logUnemp_rate & 420 & 2.096 & 0.444 & 0.642 & 3.314 & 2.192459 & 2.9718 \\
\hline logRail_lines & 418 & 8.493 & 1.103 & 5.617 & 10.51 & 0.415892 & 3.61756 \\
\hline logGoods_transpbyrail & 420 & 8.857 & 1.67 & 2.225 & 11.66 & -1.484971 & 5.91454 \\
\hline logLength_ofmotorways_eroads & 420 & 6.656 & 1.863 & 0 & 9.619 & -1.377903 & 6.680982 \\
\hline logMotorisation_rate & 420 & 6.033 & 0.294 & 4.92 & 6.501 & -1.208721 & 4.834616 \\
\hline logINV_tr & 420 & 19.23 & 2.921 & 0 & 23.04 & -4.015479 & 27.3439 \\
\hline
\end{tabular}

Source: authors' calculations using the data provided by World Doing Business, World Bank, World Economic

Forum, The World Competitiveness Yearbook, t OECD, European Commission, World Data Atlas. 
Table A3. The results of factorial analysis of the main components for estimating the status of infrastructure in the EU countries.

\begin{tabular}{lrrrr}
\hline \multicolumn{5}{c}{ Factor Analysis/Correlation, Method: Principal Factors, Rotation: (Unrotated) } \\
\hline \multicolumn{1}{c}{ Factor } & Eigenvalue & \multicolumn{1}{c}{ Difference } & Proportion & Cumulative \\
\hline Factor1 & 4.59224 & 3.38923 & 0.6639 & 0.6639 \\
Factor2 & 1.20302 & 0.41136 & 0.1739 & 0.8378 \\
Factor3 & 0.79166 & 0.29078 & 0.1144 & 0.9522 \\
Factor4 & 0.50088 & 0.31047 & 0.0724 & 1.0246 \\
Factor5 & 0.19041 & 0.03536 & 0.0275 & 1.0521 \\
Factor6 & 0.15505 & 0.07003 & 0.0224 & 1.0745 \\
Factor7 & 0.08502 & 0.02991 & 0.0123 & 1.0868 \\
Factor8 & 0.05511 & 0.13918 & 0.0080 & 1.0948 \\
Factor9 & -0.08407 & 0.03198 & -0.012 & 1.0826 \\
Factor10 & -0.11605 & 0.05707 & -0.0168 & 1.0659 \\
Factor11 & -0.17312 & 0.10944 & -0.0250 & 1.0408 \\
Factor12 & -0.28256 & 0.00000 & -0.0408 & 1.0000 \\
\hline
\end{tabular}

Source: Authors' calculations.

Table A4. Factor Loading and Explained variance.

\begin{tabular}{lrrrrrrrrr}
\hline \multicolumn{1}{c}{ Variable } & Factor1 & Factor2 & Factor3 & Factor4 & Factor5 & Factor6 & Factor7 & Factor8 & Uniqueness \\
\hline Raillinest $\sim \mathrm{m}$ & 0.9438 & 0.1013 & -0.0353 & 0.0755 & 0.1254 & -0.0722 & -0.0203 & -0.0246 & 0.0701 \\
Passengert r & 0.8668 & 0.1852 & 0.2199 & 0.0324 & -0.0104 & 0.1024 & 0.0683 & 0.0822 & 0.1430 \\
Goodstrans $\sim \mathrm{t}$ & 0.6549 & -0.0341 & -0.0929 & -0.0819 & -0.0343 & -0.4233 & 0.0032 & -0.0330 & 0.3731 \\
Lengthofmo s & 0.5295 & 0.1881 & 0.4442 & 0.0847 & 0.3109 & 0.1087 & -0.0519 & -0.0950 & 0.3596 \\
Motorisati $\sim \mathrm{e}$ & -0.0044 & 0.1972 & 0.6117 & -0.0699 & 0.0314 & -0.0157 & 0.0267 & 0.0026 & 0.5801 \\
Goodstrans d & 0.6022 & 0.2430 & 0.1903 & 0.1296 & 0.5030 & -0.0029 & 0.0353 & 0.0350 & 0.2698 \\
Goodstrans a & 0.0842 & 0.2835 & 0.0030 & 0.6372 & 0.1002 & 0.0834 & -0.0515 & 0.0460 & 0.4848 \\
Seatranspo s & 0.2342 & 0.7467 & 0.1127 & -0.0056 & 0.0549 & -0.0416 & -0.0233 & -0.0066 & 0.3695 \\
Airtransp rs & 0.5763 & 0.5731 & 0.3444 & 0.1148 & 0.2290 & 0.1848 & 0.1184 & 0.0808 & 0.1006 \\
Airtransp ds & 0.2911 & 0.2778 & 0.4350 & 0.1161 & 0.2695 & 0.1464 & 0.0320 & 0.2641 & 0.4705 \\
Infrastruc t & 0.3035 & 0.1383 & 0.3393 & 0.0430 & 0.1569 & 0.0011 & 0.2694 & 0.0310 & 0.6737 \\
INV Tr & 0.1133 & -0.3298 & 0.0134 & 0.5782 & 0.0054 & -0.0517 & 0.0885 & -0.0385 & 0.5319 \\
\hline \multicolumn{1}{c}{ Factor } & Variance & Difference & Proportion & & Cumulative & \\
\hline Factor1 & & 3.29769 & & 1.94714 & & 0.4767 & & & 0.4767 \\
Factor2 & 1.35055 & & 0.24877 & & 0.1952 & & & 0.6719 \\
Factor3 & 1.10177 & & 0.29062 & & 0.1593 & & & 0.8312 \\
Factor4 & 0.81115 & & 0.28073 & & 0.1173 & & & 0.9485 \\
Factor5 & 0.53042 & & 0.25653 & & 0.0767 & & & 1.0252 \\
Factor6 & 0.27389 & & 0.16553 & & 0.0396 & & & 1.064 \\
Factor7 & 0.10836 & & 0.00881 & & 0.0157 & & & 1.0804 \\
Factor8 & 0.09956 & & 0.00000 & & 0.0144 & & & 1.0948 \\
\hline
\end{tabular}

Source: Authors' calculations.

Table A5. Panel Unit Root Results.

\begin{tabular}{|c|c|c|c|c|c|c|c|c|}
\hline \multirow{2}{*}{$\begin{array}{l}\text { Method } \\
\text { Variable }\end{array}$} & \multicolumn{2}{|c|}{$\begin{array}{l}\text { Levin, Lin and Chu } \\
\text { (level) }\end{array}$} & \multicolumn{2}{|c|}{$\begin{array}{c}\text { IPS Stat } \\
\text { (level) }\end{array}$} & \multicolumn{2}{|c|}{$\begin{array}{c}\text { ADF-Fisher Chi-Square } \\
\text { (level) }\end{array}$} & \multicolumn{2}{|c|}{$\begin{array}{c}\text { PP-Fisher Chi-Square } \\
\text { (level) }\end{array}$} \\
\hline & Stat. & Prob & Stat. & Prob & Stat. & Prob & Stat. & Prob \\
\hline $\begin{array}{l}\text { Log economic } \\
\text { growth (level) }\end{array}$ & -3.1360 & 0.9991 & -1.5104 & 0.5052 & 59.2312 & 0.3585 & 64.4180 & 0.2058 \\
\hline Index_Transport & -34.607 & 0.0000 & -2.1162 & 0.0116 & 144.90 & 0.0000 & 172.74 & 0.0000 \\
\hline CORRP & -46.9670 & 0.0000 & -3.2546 & 0.0000 & 260.1882 & 0.0000 & 260.1882 & 0.0000 \\
\hline RedType & -15.7100 & 0.0000 & -3.6788 & 0.0188 & 204.1577 & 0.0000 & 114.4932 & 0.0000 \\
\hline QJud & -19.8794 & 0.0000 & -3.7945 & 0.0000 & 177.6331 & 0.0000 & 204.1577 & 0.0000 \\
\hline LifeExpect & -15.4517 & 0.0000 & -2.9427 & 0.0016 & 168.8009 & 0.0000 & 142.3984 & 0.0000 \\
\hline QTransPInfr & -8.3968 & 0.0000 & -0.8393 & 0.2007 & 174.3412 & 0.0000 & 106.6361 & 0.0001 \\
\hline Infl & -14.3210 & 0.0000 & -7.1672 & 0.0000 & 270.3470 & 0.0000 & 202.8990 & 0.0000 \\
\hline $\begin{array}{l}\Delta \text { Log economic } \\
\text { growth }\end{array}$ & -17.4038 & 0.0000 & -1.4361 & 0.0007 & 146.1485 & 0.0000 & 57.2800 & 0.0004 \\
\hline$\Delta$ Index_Transport & -48.1952 & 0.0000 & -13.2973 & 0.0000 & 299.9898 & 0.0000 & 175.3381 & 0.0000 \\
\hline$\Delta$ CORRP & -45.1486 & 0.0000 & -30.2299 & 0.0000 & 911.8302 & 0.0000 & 257.9483 & 0.0000 \\
\hline$\Delta$ RedType & -18.5322 & 0.0000 & -10.1178 & 0.0000 & 393.4593 & 0.0000 & 171.7382 & 0.0000 \\
\hline$\Delta$ QJud & -51.2444 & 0.0000 & -35.5581 & 0.0000 & 140,7816 & 0.0000 & 484.0911 & 0.0000 \\
\hline$\Delta$ LifeExpect & -12.4195 & 0.0000 & -0.8480 & 0.0000 & 142.1322 & 0.0000 & 161.9581 & 0.0000 \\
\hline$\Delta$ QTransPInfr & -14.9738 & 0.0000 & -1.7408 & 0.0004 & 142.4450 & 0.0000 & 106.4429 & 0.0001 \\
\hline$\Delta \operatorname{Infl}$ & -13.6138 & 0.0000 & -5.7182 & 0.0000 & 242.7962 & 0.0000 & 219.6983 & 0.0000 \\
\hline
\end{tabular}

Source: Authors' calculations. 


\section{References}

1. Wang, L.; Xue, X.; Zhao, Z.; Wang, Z. The Impacts of Transportation Infrastructure on Sustainable Development: Emerging Trends and Challenges. Int. J. Environ. Res. Public Health 2018, 15, 1172. [CrossRef] [PubMed]

2. Arvin, M.B.; Pradhan, R.P.; Norman, N.R. Transportation intensity, urbanization, economic growth, and $\mathrm{CO}_{2}$ emissions in the g-20 countries. Util. Policy 2015, 35, 50-66. [CrossRef]

3. Beyzatlar, M.A.; Karacal, M.; Yetkiner, H. Granger-causality between transportation and GDP: A panel data approach. Transp. Res. Part A Policy Pract. 2014, 63, 43-55. [CrossRef]

4. Pradhan, R.P.; Bagchi, T.P. Effect of transportation infrastructure on economic growth in India: The VECM approach. Res. Transp. Econ. 2013, 38, 139-148. [CrossRef]

5. Pradhan, R.P.; Arvin, M.B.; Norman, N.R.; Belee, S.K. Economic growth and the development of telecommunications infrastructure in the G-20 countries: A Panel-VAR Approach. Telecommun. Policy 2014, 38, 634-649. [CrossRef]

6. Phang, S. Strategic development of airport and rail infrastructure: The case of Singapore. Transp. Policy 2003, 10, 27-33. [CrossRef]

7. Moomaw, R.L.; Williams, M. Total factor productivity growth in manufacturing: Further evidence from the States. J. Reg. Sci. 1991, 31, 17-34. [CrossRef]

8. Démurger, S. Infrastructure development and economic growth: An explanation for regional disparities in China? J. Comp. Econ. 2001, 29, 95-117. [CrossRef]

9. Cantos, P.; Gumbau-Albert, M.; Maudos, J. Transport infrastructures, spillover effects and regional growth: Evidence of the Spanish case. Transp. Rev. 2005, 25, 25-50. [CrossRef]

10. Berechman, J.; Ozmen, D.; Ozbay, K. Empirical analysis of transportation investment and economic development at state, county and municipality levels. Transportation 2006, 33, 537-551. [CrossRef]

11. Sahoo, P.; Dash, R.K. Infrastructure development and economic growth in India. J. Asia Pac. Econ. 2009, 14, 351-365. [CrossRef]

12. Hong, J.J.; Chu, Z.F.; Wang, Q. Transport infrastructure and regional economic growth: Evidence from China. Transportation 2011, 38, 737-752. [CrossRef]

13. Jiwattanakulpaisarn, P.; Noland, R.B.; Graham, D.J. Marginal productivity of expanding highway capacity. J. Transp. Econ. Policy 2012, 46, 333-347.

14. Deng, T.T.; Shao, S.; Yang, L.L.; Zhang, X.L. Has the transport-led economic growth effect reached a peak in china? A panel threshold regression approach. Transportation 2014, 41, 567-587. [CrossRef]

15. Lee, D.S.; Pitari, G.; Grewe, V.; Gierens, K.; Penner, J.E.; Petzold, A.; Prather, M.J.; Schumann, U.; Bais, A.; Berntsen, T.; et al. Transport impacts on atmosphere and climate: Aviation. Atmos. Environ. 2010, 44, 4678-4734. [CrossRef]

16. Abdallah, K.B.; Belloumi, M.; De Wolf, D. Indicators for sustainable energy development: A multivariate cointegration and causality analysis from tunisian road transport sector. Renew. Sustain. Energy Rev. 2013, 25, 34-43. [CrossRef]

17. Saboori, B.; Sapri, M.; bin Baba, M. Economic growth, energy consumption and $\mathrm{CO}_{2}$ emissions in OECD (organization for economic co-operation and development)'s transport sector: A fully modified bi-directional relationship approach. Energy 2014, 66, 150-161. [CrossRef]

18. Farhadi, M. Transport infrastructure and long-run economic growth in OECD countries. Transp. Res. A Policy Pract. 2015, 74, 73-90. [CrossRef]

19. Sousa, C.; Roseta-Palma, C.; Martins, L.F. Economic growth and transport: On the road to sustainability. Nat. Resour. Forum 2015, 39, 3-14. [CrossRef]

20. Bröcker, J.; Rietveld, P. Infrastructure and regional development. In Handbook of Regional Growth and Development Theories; Capello, R., Nijkamp, P., Eds.; Edward Elgar: Cheltenham, UK, 2009; pp. 152-181.

21. World Bank. World Development Report (WDR); Oxford University Press: Oxford, UK, 1994.

22. Barro, R.J. Government spending in a simple model of endogeneous growth. J. Political Econ. 1990, 98, 103-125. [CrossRef]

23. Aschauer, D.A. Is public expenditure productive? J. Monet. Econ. 1989, 23, 177-200. [CrossRef]

24. Aschauer, D.A. Public investment and productivity growth in the group of seven. Econ. Perspect. 1989, 13, 17-25. 
25. Munnell, A.H. How does public infrastructure affect regional economic performance? N. Engl. Econ. Rev. 1990, September/October, 11-32.

26. Baum, H. Social Benefits of Road Transport; University of Cologne: Cologne, Germany, 1998.

27. Goodwin, P.; Persson, S. Assessing the Benefits of Transport; ECMT Report; OECD: Paris, France, 2001.

28. Hu, A.; Liu, S. Transportation, economic growth and spillover effects: The conclusion based on the spatial econometric model. Front. Econ. China 2010, 5, 169-186. [CrossRef]

29. Canning, D.; Pedroni, P. Infrastructure, long-run economic growth and causality tests for cointegrated panels. Manch. Sch. 2008, 76, 504-527. [CrossRef]

30. Crafts, N. Transport infrastructure investment: Implications for growth and productivity. Oxf. Rev. Econ. Policy 2009, 25, 327-343. [CrossRef]

31. Zhou, T.; Tan, R.; Sedlin, T. Planning Modes for Major Transportation Infrastructure Projects (MTIPs): Comparing China and Germany. Sustainability 2018, 10, 3401. [CrossRef]

32. Bhatta, S.D.; Drennan, M.P. The Economic Benefits of Public Investment in Transportation: A Review of Recent Literature. J. Plan. Educ. Res. 2003, 22, 288-296. [CrossRef]

33. Lakshmanan, T.R. The Wider Economic Benefits of Transportation: An Overview; OECD International Transport Forum; Discussion Paper, 08; Joint Transport Research Centre, OECD: Paris, France, 2007.

34. Mohmand, Y.T.; Wang, A.H.; Saeed, A. The impact of transportation infrastructure on economic growth: Empirical evidence from pakistan. Transp. Lett. 2016, 9, 63-69. [CrossRef]

35. Bougheas, S.; Demetriades, P.O.; Mamuneas, T.P. Infrastructure, specialization, and economic growth. Can. J. Econ. 2000, 33, 506-522. [CrossRef]

36. Aschauer, D.A. Highway capacity and economic growth. Econ. Perspect. 1990, 14, 14-24.

37. Garcia-Milla, T.; McGuire, T.J. The contribution of publicly provided inputs to States' economies. Reg. Sci. Urban Econ. 1992, 22, 229-241. [CrossRef]

38. Pereira, A.M. Is all public capital created equal? Rev. Econ. Stat. 2000, 82, 513-518. [CrossRef]

39. Banister, D. Transport and economic development: Reviewing the evidence. Transp. Rev. 2012, 32, 1-2. [CrossRef]

40. Gherghina, S.C.; Onofrei, M.; Vintila, G.; Armeanu, D.S. Empirical Evidence from EU-28 Countries on Resilient Transport Infrastructure Systems and Sustainable Economic Growth. Sustainability 2018, 10, 2900. [CrossRef]

41. Li, J.; Wen, J.X.; Jiang, B. Spatial spillover effects of transport infrastructure in Chinese new silk road economic belt. Int. J. E-Navig. Marit. Econ. 2017, 6, 1-8. [CrossRef]

42. Baker, D.; Merkert, R.; Kamruzzaman, M. Regional aviation and economic growth: Cointegration and causality analysis in Australia. J. Transp. Geogr. 2015, 43, 140-150. [CrossRef]

43. Chi, J.; Baek, J. Dynamic relationship between air transport demand and economic growth in the United States: A new look. Transp. Policy 2013, 29, 257-260. [CrossRef]

44. Marazzo, M.; Scherre, R.; Fernandes, E. Air transport demand and economic growth in Brazil: A time series analysis. Transp. Res. E Logist. Transp. Rev. 2010, 46, 261-269. [CrossRef]

45. Bottasso, A.; Conti, M.; Ferrari, C.; Tei, A. Ports and regional development: A spatial analysis on a panel of European regions. Transp. Res. A Policy Pract. 2014, 65, 44-55. [CrossRef]

46. Park, J.S.; Seo, Y.J. The impact of seaports on the regional economies in South Korea: Panel evidence from the augmented Solow model. Transp. Res. E Logist. Transp. Rev. 2016, 85, 107-119. [CrossRef]

47. Munim, Z.H.; Schramm, H.J. The impacts of port infrastructure and logistics performance on economic growth: The mediating role of seaborne trade. J. Ship. Trade 2018, 3, 1-19. [CrossRef]

48. Evans, P.; Karras, G. Are government activities productive? Evidence from a panel of U.S. states. Rev. Econ. Stat. 1994, 76, 1-11. [CrossRef]

49. Chandra, A.; Thompson, E. Does public infrastructure affect economic activity? Evidence from the rural interstate highway system. Reg. Sci. Urban Econ. 2000, 30, 457-490. [CrossRef]

50. Hossain, M.S. Panel estimation for $\mathrm{CO}_{2}$ emissions, energy consumption, economic growth, trade openness and urbanization of newly industrialized countries. Energy Policy 2011, 39, 6991-6999. [CrossRef]

51. Liddle, B.; Lung, S. The long-run causal relationship between transport energy consumption and GDP: Evidence from heterogeneous panel methods robust to cross-sectional dependence. Econ. Lett. 2013, 121, 524-527. [CrossRef] 
52. Salim, R.A.; Shafiei, S. Urbanization and renewable and non-renewable energy consumption in OECD countries: An empirical analysis. Econ. Model. 2014, 38, 581-591. [CrossRef]

53. Lean, H.H.; Huang, W.; Hong, J. Logistics and economic development: Experience from China. Transp. Policy 2014, 32, 96-104. [CrossRef]

54. Yu, N.N.; De Jong, M.; Storm, S.; Mi, J.N. Transport infrastructure, spatial clusters and regional economic growth in China. Transp. Rev. 2012, 32, 3-28. [CrossRef]

55. Eruygur, A.; Kaynak, M.; Mert, M. Transportation-communication capital and economic growth: A VECM analysis for Turkey. Eur. Plan. Stud. 2012, 20, 341-363. [CrossRef]

56. Lean, C.S. Empirical tests to discern linkages between construction and other economic sectors in Singapore. Constr. Manag. Econ. 2001, 19, 355-363. [CrossRef]

57. Dinda, S.; Coondoo, D. Income and emissions: A panel-based cointegration analysis. Ecol. Econ. 2011, 57, 167-181. [CrossRef]

58. Chia, F.C. Revisiting the 'Bon Curve'. Constr. Manag. Econ. 2011, 29, 695-712. [CrossRef]

59. Tervo, H. Centres and peripheries in Finland: Granger causality tests using panel data. Spat. Econ. Anal. 2009, 4, 377-390. [CrossRef]

60. Anaman, K.A.; Osei-Amponsah, C. Analysis of the causality links between the growth of the construction industry and the growth of the macro-economy in Ghana. Constr. Manag. Econ. 2007, 25, 951-961. [CrossRef]

61. Mukkala, K.; Tervo, H. Air transportation and regional growth: Which way does the causality run? Environ. Plan. A 2013, 45, 1508-1520. [CrossRef]

62. Brida, J.G.; Bukstein, D.; Zapata-Aguirre, S. Dynamic relationship between air transport and economic growth in italy: A time series analysis. Int. J. Aviat. Manag. 2016, 3, 52-67.

63. Fernandes, E.; Pacheco, R.R. The causal relationship between GDP and domestic air passenger traffic in Brazil. Transp. Plan. Technol. 2010, 33, 569-581. [CrossRef]

64. Maparu, T.S.; Mazumder, T.N. Transport infrastructure, economic development and urbanization in india (1990-2011): Is there any causal relationship? Transp. Res. A Policy Pract. 2017, 100, 319-336. [CrossRef]

65. Kustepeli, Y.; Gulcan, Y.; Akgungor, S. Transportation infrastructure investment, growth and International trade in Turkey. Appl. Econ. 2012, 44, 2619-2629. [CrossRef]

66. Saboori, B.; Sulaiman, J.; Mohd, S. Economic growth and $\mathrm{CO}_{2}$ emissions in Malaysia: A cointegration analysis of the environmental Kuznets curve. Energy Policy 2012, 51, 184-191. [CrossRef]

67. Sobrino, N.; Monzon, A. The impact of the economic crisis and policy actions on GHG emissions from road transport in Spain. Energy Policy 2014, 74, 486-498. [CrossRef]

68. Shahbaz, M.; Khraief, N.; Ben Jemaa, M.M. On the causal nexus of road transport $\mathrm{CO}_{2}$ emissions and macroeconomic variables in Tunisia: Evidence from combined cointegration tests. Renew. Sustain. Energy Rev. 2015, 51, 89-100. [CrossRef]

69. Liu, Z.; Li, L.; Zhang, Y.J. Investigating the $\mathrm{CO}_{2}$ emission differences among China's transport sectors and their influencing factors. Nat. Hazards 2015, 77, 1323-1343. [CrossRef]

70. Song, L.L.; Mi, J.N. Port infrastructure and regional economic growth in China: A granger causality analysis. Marit. Policy Manag. 2016, 43, 456-468. [CrossRef]

71. Yang, S.; He, L.Y. Transport pollution in China-Evidence from Beijing. Energy Environ. UK 2016, 27, $377-388$. [CrossRef]

72. Atte-Oudeyi, B.; Kestemont, B.; De Meulemeester, J.L. Road Transport, Economic Growth and Carbon Dioxide Emissions in the Briics: Conditions for a Low Carbon Economic Development; CEB Working Paper 16/023; Centre Emile Bernheim: Brussels, Belgium, 2016.

73. Xie, R.; Fang, J.Y.; Liu, C.J. Impact and spatial spillover effect of transport infrastructure on urban environment. Energy Procedia 2016, 104, 227-232. [CrossRef]

74. Alshehry, A.S.; Belloumi, M. Study of the environmental kuznets curve for transport carbon dioxide emissions in saudi arabia. Renew Sustain. Energy Rev. 2017, 75, 1339-1347. [CrossRef]

75. Ben Jebli, M.; Belloumi, M. Investigation of the causal relationships between combustible renewables and waste consumption and $\mathrm{CO}_{2}$ emissions in the case of tunisian maritime and rail transport. Renew. Sustain. Energy Rev. 2017, 71, 820-829. [CrossRef]

76. Neves, S.A.; Marques, A.C.; Fuinhas, J.A. Is energy consumption in the transport sector hampering both economic growth and the reduction of $\mathrm{CO}_{2}$ emissions? A disaggregated energy consumption analysis. Transp. Policy 2017, 59, 64-70. [CrossRef] 
77. Saidi, S.; Hammami, S. Modeling the causal linkages between transport, economic growth and environmental degradation for 75 countries. Transp. Res. D Transp. Environ. 2017, 53, 415-427. [CrossRef]

78. Xie, R.; Fang, J.Y.; Liu, C.J. The effects of transportation infrastructure on urban carbon emissions. Appl. Energy 2017, 196, 199-207. [CrossRef]

79. Damania, R.; Russ, J.; Wheeler, D.; Barra, A.F. The road to growth: Measuring the tradeoffs between economic growth and ecological destruction. World Dev. 2018, 101, 351-376. [CrossRef]

80. Yang, M.; Ma, T.M.; Sun, C.W. Evaluating the impact of urban traffic investment on $\mathrm{SO}_{2}$ emissions in China cities. Energy Policy 2018, 113, 20-27. [CrossRef]

81. Sun, C.W.; Luo, Y.; Li, J.L. Urban traffic infrastructure investment and air pollution: Evidence from the 83 cities in China. J. Clean. Prod. 2018, 172, 488-496. [CrossRef]

82. Ben Jebli, M.; Hadhri, W. The dynamic causal links between $\mathrm{CO}_{2}$ emissions from transport, real GDP, energy use and international tourism. Int. J. Sustain. Dev. World Ecol. 2018, 25, 568-577. [CrossRef]

83. Zawieska, J.; Pieriegud, J. Smart city as a tool for sustainable mobility and transport decarbonisation. Transp. Policy 2018, 63, 39-50. [CrossRef]

84. Linton, C.; Grant-Muller, S.; Gale, W.F. Approaches and techniques for modelling $\mathrm{CO}_{2}$ emissions from road transport. Transp. Rev. 2015, 35, 533-553. [CrossRef]

85. European Commission. Europe 2020 Strategy. Available online: https://ec.europa.eu/info/business-economyeuro/economic-and-fiscal-policy-coordination/eu-economic-governance-monitoring-prevention-correction/ european-semester/framework/europe-2020-strategy_en (accessed on 2 October 2018).

86. Radziszewski, P.; Nazarko, J.; Vilutiene, T.; Dębkowska, K.; Ejdys, J.; Gudanowska, A.; Halicka, K.; Kilon, J.; Kononiuk, A.; Kowalski, K.J.; et al. Future Trends in Road Pavement Technologies Development in the Context of Environmental Protection. Baltic J. Road Bridge Eng. 2016, 11, 160-168. [CrossRef]

87. Esfahani, H.S.; Ramirez, M.T. Institutions, infrastructure, and economic growth. J. Dev. Econ. 2003, 70, 443-477. [CrossRef]

88. Pereira, A.M.; Andraz, J.M. Public investment in transportation infrastructure and economic performance in Portugal. Rev. Dev. Econ. 2005, 9, 177-196. [CrossRef]

89. Agénor, P.R.; Moreno-Dodson, B. Public Infrastructure and Growth: New Channels and Policy Implications; The World Bank: Washington, DC, USA, 2006. [CrossRef]

90. OECD Database 2018. Available online: https:/ / data.oecd.org/ (accessed on 1 November 2018).

91. European Commission. Eurostat Database 2018. Available online: https://ec.europa.eu/eurostat/data/ database (accessed on 19 September 2018).

92. Medina, L.; Schneider, F. Shadow Economies around the World: What Did We Learn Over the Last 20 Years? IMF Working Paper No. 18/17; International Monetary Fund (IMF): Washington, DC, USA, 2018.

93. Schneider, F. Size and Measurement of the Informal Economy in 110 Countries Around the World; World Data Atlas: Washington, DC, USA, 2002.

94. Schneider, F.; Buehn, A.; Montenegro, C. Shadow Economies All over the World New Estimates for 162 Countries from 1999 to 2007; PRWP 5356; The World Bank: Washington, DC, USA, 2010.

95. World Bank Database. 2018. Available online: https://data.worldbank.org/ (accessed on 28 August 2018).

96. World Economic Forum. 2018. Available online: https://www.weforum.org/ (accessed on 8 October 2018).

97. The World Competitiveness Yearbook. 2018. Available online: https://worldcompetitiveness.imd.org/ (accessed on 10 September 2018).

98. Hakim, M.M.; Merkert, R. The causal relationship between air transport and economic growth: Empirical evidence from South Asia. J. Transp. Geogr. 2016, 56, 120-127. [CrossRef]

99. Baumöhl, E.; Lyocsa, S. Stationarity of time series and the problem of spurious regression. SSRN 2009. [CrossRef]

100. Hodge, G.A.; Greve, C. Public-private partnerships: An international performance review. Public Adm. Rev. 2007, 67, 545-558. [CrossRef]

101. Koppenjan, J.J. The formation of public-private partnerships: Lessons from nine transport infrastructure projects in The Netherlands. Public Adm. 2005, 83, 135-157. [CrossRef]

102. Estache, A.; Serebrisky, T. Where Do We Stand on Transport Infrastructure Deregulation and Public-Private Partnership? The World Bank: Washington, DC, USA, 2004.

103. Afonso, A.; Schuknecht, L.; Tanzi, V. Public Sector Efficiency: An International Comparison; Working Paper 242/July; European Central Bank: Frankfurt, Germany, 2003. 
104. Afonso, A.; Schuknecht, L.; Tanzi, V. Public sector efficiency: An international comparison. Public Choice 2005, 123, 321-347. [CrossRef]

105. Eck, N.J.; Waltman, L. How to normalize cooccurrence data? An analysis of some well-known similarity measures. J. Am. Soc. Inf. Sci. Technol. 2009, 60, 1635-1651. [CrossRef]

106. Achour, H.; Belloumi, M. Investigating the causal relationship between transport infrastructure, transport energy consumption and economic growth in tunisia. Renew. Sustain. Energy Rev. 2016, 56, 988-998. [CrossRef]

107. Calderón, C.; Servén, L. The Effects of Infrastructure Development on Growth and Income Distribution; The World Bank: Washington, DC, USA, 2004.

108. Calderón, C. Infrastructure and Growth in Africa; The World Bank: Washington, DC, USA, 2009.

109. Donaubauer, J.; Meyer, B.E.; Nunnenkamp, P. A new global index of infrastructure: Construction, rankings and applications. World Econ. 2016, 39, 236-259. [CrossRef]

110. Philippe, M. Can regional policies affect growth and geography in Europe? World Econ. 1998, 21, 757-774.

111. Waverman, L.; Meschi, M.; Fuss, M. The impact of telecoms on economic growth in developing countries. Vodafone Policy Pap. Ser. 2005, 2, 10-24.

112. Major, I. Private and public infrastructure in Eastern Europe. Oxf. Rev. Econ. Policy 1991, 7, 76-92. [CrossRef]

113. Palei, T. Assessing the impact of infrastructure on economic growth and global competitiveness. Procedia Econ. Financ. 2015, 23, 168-175. [CrossRef]

114. Hanushek, E.; Wößmann, L. The Role of Education Quality for Economic Growth; The World Bank: Washington, DC, USA, 2007.

115. Prachowny, M.F. Okun's law: Theoretical foundations and revised estimates. Rev. Econ. Stat. 1993, 75, 331-336. [CrossRef]

116. Soylu, Ö.B.; Çakmak, I.; Okur, F. Economic growth and unemployment issue: Panel data analysis in Eastern European Countries. J. Int. Stud. 2018, 11, 93-107. [CrossRef] [PubMed]

117. Schneider, F. The Influence of Public Institutions on the Shadow Economy: An Empirical Investigation for OECD Countries. Eur. J. Law Econ. 2010, 6, 441-468. [CrossRef]

118. Schneider, F.; Willams, C.C. The Shadow Economy; IEA: London, UK, 2013.

119. Francois, J.; Manchin, M. Institutional Quality, Infrastructure, and the Propensity to Export; World Bank: Washington, DC, USA, 2006.

120. Jalilian, H.; Kirkpatrick, C.; Parker, D. The impact of regulation on economic growth in developing countries: A cross-country analysis. World Dev. 2007, 35, 87-103. [CrossRef]

121. Nicoletti, G.; Scarpetta, S. Regulation, productivity and growth: OECD evidence. Econ. Policy 2003, 18, 9-72. [CrossRef]

122. Easterly, W. Life during growth. J. Econ. Growth 1999, 4, 239-276. [CrossRef]

123. Bassanini, A.; Scarpetta, S.; Hemmings, P. Economic Growth: The Role of Policies and Institutions. Panel Data Evidence from OECD Countries; OECD: Paris, France, 2001.

124. Habib, M.M.; Mileva, E.; Stracca, L. The real exchange rate and economic growth: Revisiting the case using external instruments. J. Int. Money Financ. 2017, 73, 386-398. [CrossRef]

125. Schneider, F. Size and Development of the Shadow Economies of 157 Countries Worldwide-1999 to 2013. Available online: https:// knoema.com/atlas/sources/Friedrich-Schneider (accessed on 17 September 2018).

126. UNESCO Institute for Statistics. 2018. Available online: http:/ / uis.unesco.org/ (accessed on 12 August 2018).

(C) 2018 by the authors. Licensee MDPI, Basel, Switzerland. This article is an open access article distributed under the terms and conditions of the Creative Commons Attribution (CC BY) license (http://creativecommons.org/licenses/by/4.0/). 